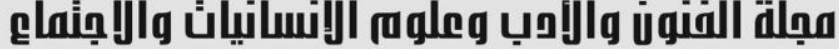

Journal of Arts, Literature, Humanities and Social Sciences

www.jalhss.com

\section{Sherman Alexie: Poet of the Reservations}

Assist. Prof. Dr. Nabil Mohammed Ali Al-Jibouri

Department of English Language Teaching - College of Education Knowledge University - Kurdistan Region, Iraq

Email: nabil.ali@knu.edu.iq

\section{ABSTRACT}

Sherman Alexie is a Native American poet, novelist, short story writer, essayist, comedian, filmmaker and scriptwriter. He represents a new generation of Native American writers in the 1990s.

The aim of this article is to show that Alexie can be described as the poet of the Reservations because he is interested in truthfully portraying the social, political, economic, and cultural aspects of the lives of Native Americans living on Reservations.

Keywords: Sherman Alexie, Reservations, Native Americans, Native American Poetry. 


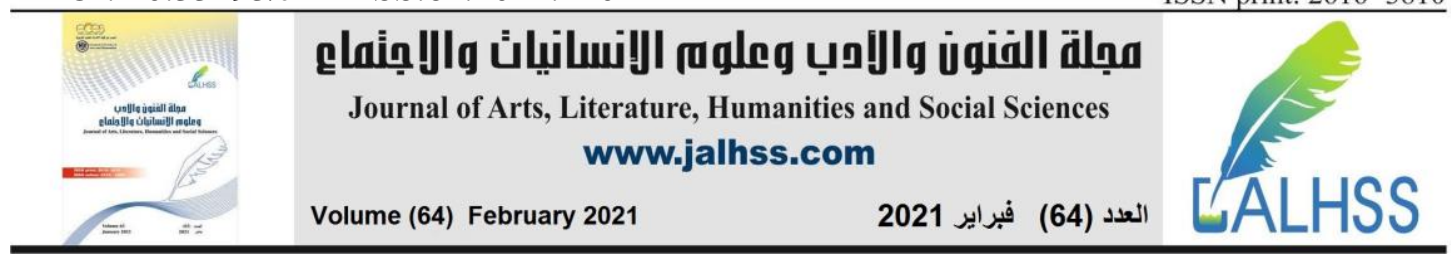

\section{Sherman Alexie: Poet of the Reservations}

"But we reservation Indians don't get to realize our dreams. We don't get those chances. Or choices. We're just poor. That's all we are." (Alexie, The Absolutely True Diary of a Part Time Indian 13).

\section{Introduction}

A Reservation is a land assigned for Native Americans to live on because The U.S. government thought that the Native Americans could no longer live among the white settlers, "the policy of preservation by gradual concentration on territorial reserves was the only alternative to swift extermination by the sword and famine." The other real reasons for establishing these Reservations were to bring Native Americans under U.S. government control and to assimilate them within the dominant Euro-American culture. This forced confinement on Reservations had overwhelming and disastrous effects on Native Americans. Kai Erikson describes these Reservations as a "gathering place for the wounded." Richard King links them to a tomb. ${ }^{3}$ Sherman Alexie describes them as "concentration camps."4

Most of these Native American reservations are regions of extreme poverty with high rates of alcoholism and drug abuse. They lack any kind of economic development or income source other than natural resource extraction. Poverty rates on the reservations are more than double the national average which reflects the fact that Native Americans occupy the lowest economic level in the American society. As indicated in the 1990 census report, 31.6 percent of the Native Americans live below the poverty line, compared to an average of 13.1 percent of all other races in the United States. ${ }^{5}$ Native Americans living on reservations suffer under the dual burden of the highest unemployment rates and the lowest average incomes in the United States. These problems cause poor housing, lack of education, and meager health care services. Jace Weaver explains these conditions:

The average yearly income is half the poverty level, and over half of all Natives are unemployed. On some reservations, unemployment runs as high as 85-90 percent. Health statistics chronically rank Natives at or near the bottom. Male life expectancy is forty-four years, and female is forty-seven .... Substance abuse, suicide, crime, and violence are major problems among both urban and reservation populations. ${ }^{6}$

The Native American health level is the lowest and disease rates the highest of all major population groups in the United States. According to Rennard Strickland:

The incidence of tuberculosis is 400 percent higher than the national average. Similar statistics show that the incidence of strep infections is 1,000 percent, meningitis is 


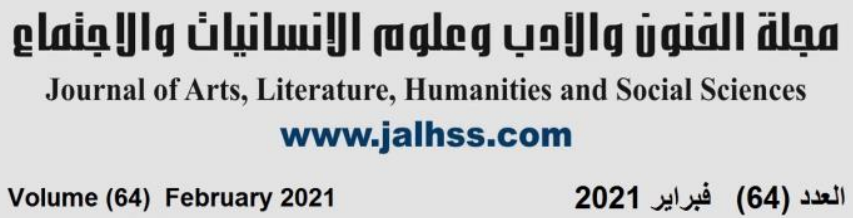

Volume (64) February 2021

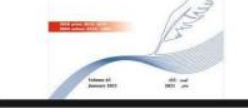

2,000 percent higher and dysentery is 10,000 percent higher. Death rates are shocking when native and non-native populations are compared. Influenza and pneumonia are 300 percent greater killers among Indians. Diseases such as hepatitis are in epidemic proportions, with an 800 percent higher chance of death. Diabetes is almost a plague. ${ }^{7}$

\section{Sherman Alexie: Poet of the Reservations}

Sherman Alexie Jr. (1966- ) is a well-known Native American poet, novelist, short story writer, and filmmaker. Alexie has published nine books of poetry; The Business of Fancy-Dancing(1992), I would Steal Horses ( 1992), First Indian on the Moon ( 1993), Old Shirts \& New Skins ( 1993), Water Flowing Home (1995), The Sumer of Black Widows ( 1996), The Man Who loves Salmon (1998), One Stick Song ( 2000), and Face ( 2009).

Lynn Cline indicates that Alexie's work "carries the weight of five centuries of colonization, retelling the American Indian struggle to survive, painting a clear, compelling, and often painful portrait of modern Indian life." ${ }^{8}$ Alexie's poetry is concerned with the depiction of Native Americans living on Reservation. Alexie himself grew up on the Spokane reservation in Spokane, Washington, therefore his upbringing has profound impact on his poetry. He says:

I am a Spokane/Coeur d'Alene Indian from Wellpinit, Washington, where I live on the Spokane Indian reservation. Everything I do now, writing and otherwise, has its origin in that. ${ }^{9}$

The Spokane Reservation is an actual place where Alexie finds literary sources for his writing:

Every theme, every story, every tragedy that exists in literature takes place in my little community. Hamlet takes place on my reservation daily. King Lear takes place on my reservation daily. It's a powerful place. I'm never going to run out of stories." 10

In an interview, Alexie said, "I want my literature to concern the daily lives of Indians, I think most Native American literature is so obsessed with nature that I don't think it has any useful purpose." ${ }^{11} \mathrm{He}$ is especially critical of what he has called the "corn pollen, four directions, eagle feather, Mother Earth, Father Sky" school of Native American literature." ${ }^{12} \mathrm{He}$ believes that:

Native Americans at the end of the twentieth century had to adopt different survival strategies from previous ones: "This was the generation of HUD house, of car wreck and cancer, of commodity cheese and beef. These were the children who carried dreams in the back pockets of their blue jeans, pulled them out easily, traded back and forth." ${ }^{13}$ 


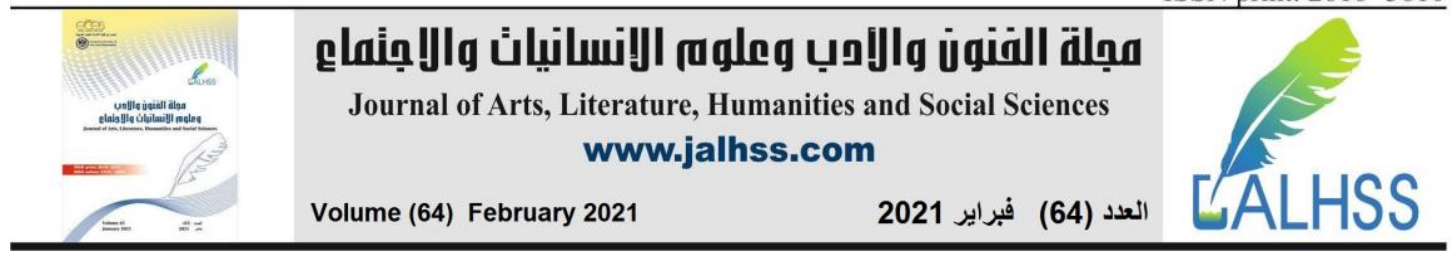

Consequently, Alexie is interested in truthfully portraying the social, political, economic, and cultural aspects of the lives of Native Americans living on reservations.

The harsh effects of everyday living conditions on Reservations have led to intense anger among Native Americans. Anger by itself can be self-destructive without finding a proper outlet. Therefore, Alexie's anger is tempered by a sense of humor, more particularly dark humor. ${ }^{14}$ For him humor, formed partly by such techniques as parody, satire, burlesque, hyperbole, and farce, is an effective strategy to deal with the crises of Native Americans living on reservations. Paula Gunn Allen claims that "Humor softens their [Native Americans] anger, celebrates their survival." ${ }^{15}$ She adds that "Humor is a primary means of reconciling the tradition of continuance, bonding, and celebration with the stark facts of racial destruction." 16 For modern Native American writers, humor becomes a means for survival. Louise Erdrich explains this idea:

The one universal thing about Native Americans from tribe to tribe, is the survival humor... to live with what you have to live with ... you have to be able to poke fun at people who are dominating your life and your family ... and almost the most serious things have to be jokes, I think. It's the way we deal with the most difficult events in our lives. ${ }^{17}$

Alexie himself claims that "Humor is self-defense on the rez. You make people laugh and you disarm them. You can say controversial or rowdy things and they'll listen or laugh." 18 The Native American scholar Jane Hafen asserts that she enjoys Alexie's writings because:

They make me laugh. In the face of dismal reservation life, urban crisis of self, community, and identity, he can make me laugh, often by inverting imagery and turning inside jokes. He helps make the pain bearable." ${ }^{\prime 9}$

Alexie utilizes dark humor as "an effective strategy to point out historical and present conditions of inequality created by white hegemony and convey conflicts generated by assimilation." 20 Alexie uses dark humor in the poem "Futures" to criticize the vicious circle of poverty and alcoholism that often pervade the lives of Native Americans living on reservations. The poem begins with an epigraph that reads, "oh children, think about the good times." $(B F D, 35)^{21}$ Ironically, in response to the epigraph, Alexie details poverty on the Reservation. He presents a realistic portrait of the Reservation and its inhabitants:

We lived in the HUD ${ }^{22}$ house

for fifty bucks a month.

Those were the good times.

ANNIE GREEN SPRINGS WINE

was a dollar a bottle. 


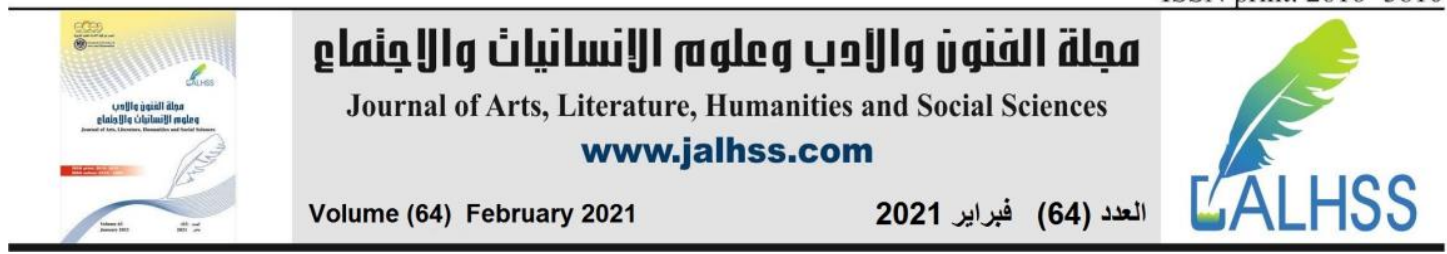

My uncles always came over

to eat stew and fry bread

to get drunk in the sweatlodge

to spit and piss in the fire. $(B F D, 35)$

Despite having no money and little food, the starving boy and his father in the poem "Travelling" find humor in their bleak situation as a means to cope with hunger and poverty:

It was hunger made me move then, not a dream, and I reached down and rummaged through the cooler for something to eat, drink. Two slices of bread, a half-full Pepsi, melting ice. My hand was cold when I touched my father's arm. $(B F D, 13)$

When the boy only finds two slices of bread in the whole van, he asks his father:

Hey Dad, we ain't got any food left."

"What's in your hand?"

"just two slices of bread."

"Well, you can have a jam sandwich, enit'

"What's that?"

"You just take two slices of bread

and jam them together." (BFD, 13)

In his prose poem "The Unauthorized Autobiography of Me," Alexie describes the complexities of his reservation childhood. He remembers coming home after a snowball fight with his cousins during the winter of 1976 in a scene which exemplifies the age-old repercussions of being poor:

When I step into the house, my mother is sewing yet another quilt. She is singing a song under her breath. You might assume she is singing a highly traditional Spokane Indian song. In fact, she is singing Donna Fargo's "The Happiest Girl in the Whole USA." Improbably, this is a highly traditional Spokane Indian song. The living room is dark in the late afternoon. The house is cold. My mother is wearing her coat and shoes.

"Why don't you turn up the heat?" I ask my mother. "No electricity," she says. Power went out?"I ask. "Didn't pay the bill," she says.

I am colder. I inhale, exhale, my breath visible inside the house. I can hear a car sliding on the icy road outside. My mother is making a quilt. This quilt will pay for the electricity. Her fingers are stiff and painful from the cold. She is sewing as fast as she can. $(\text { OSNS }, 15)^{23}$

Alexie details the encroaching poverty on the Spokane Reservation which consistently threatened his family. He tempers the seriousness of the situation with black humor by recalling his mother singing a "highly traditional Spokane Indian song" by Donna 


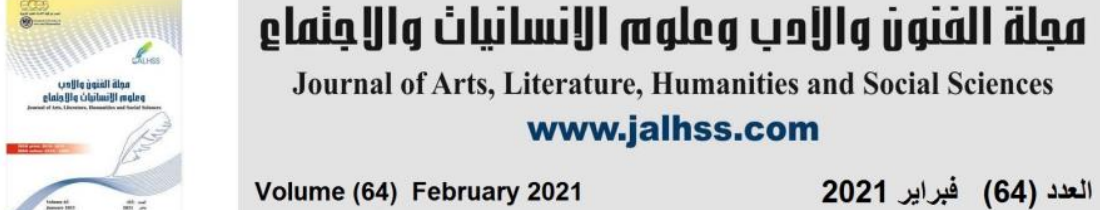

Fargo. Of course, the circumstances emphasize the irony of the song; a Native woman on a reservation sewing a quilt to sell so she can get the electricity turned back on and feed her family could hardly be termed "The Happiest Girl in the Whole USA."

In "The Unauthorized Biography of Lester Falls Apart" Alexie writes about a Native American homeless man named Lester, who struggles to survive amidst harsh economic conditions. Through Lester, Alexie condemns the bleak circumstances on the reservation and how they often destroy pride and dignity of Native Americans:

Stray dogs

Sleep next to Lester

Close To whatever warmth

He has left. (OSNS, 49)

To Lester, who was awarded the Purple Heart Medal for his service in Vietnam, there is no real difference between Vietnam and the reservation:

In your mind

Vietnam and the reservation

fancydance together. (OSNS, 50)

In "Architecture", Alexie addresses the spatial and psychological restrictions of the reservation. He establishes a connection or cause-and effect relationship between the physical conditions of the reservation and the mental confinement it helps produce. He writes, making reference to the paltry, monotonous HUD houses common on the reservation:

The reservation is full of these rooms

where four walls make a home. Foot by foot, we measure definitions

assigned to us by years. We draw lines

bisecting what never changes and what does

is the distance between

touching and becoming. There are promises

we can map across landscape

of our body, becoming more of what matters

in a house without doors or windows. (OSNS,7)

In measuring the rooms, Alexie demonstrates the connection between the lived space on the reservation and the historical constraints imposed on Native Americans who live on Reservations. The "rooms / where four walls make a home"(OSNS,7) function as mini-Reservations, becoming smaller enclosures rather than offering the sanctuary implied by the term "home." The bleak conditions drive the residents into a meager living, fighting for survival: 


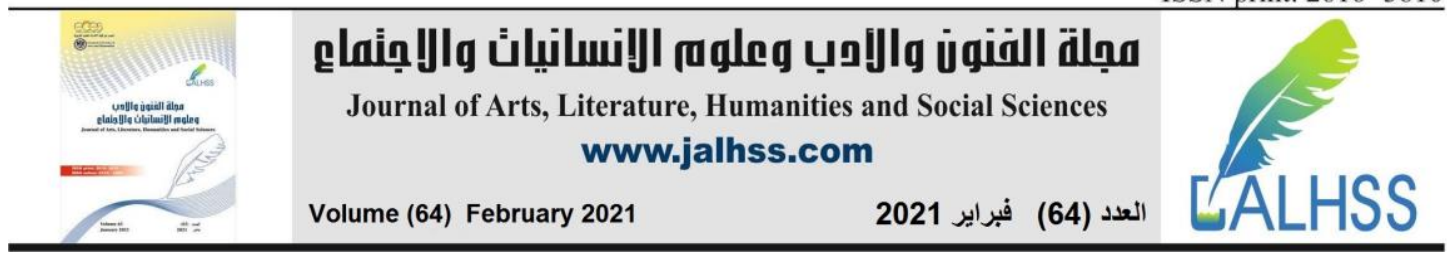

where hands are the weapon, pressed

tightly against its heartbeat, breaking us

down into everything we want to own. (OSNS,7)

The prose poem "Geometry" expresses Alexie's anger at the monotonous and confined life on Reservation:

Mornings, I measure the length and width of my basement bedroom in the HUD house. Like most on the reservation, our house is unfinished, and I'm worried that something will change while I sleep.

The ceremony is the same: I wake, shower, comb my hair into braids, take my tape measure from its hiding place and work quietly and quickly. The tape measure I stole from the BIA, its maximum length is 12 feet and I worry the reservation will become smaller every time inventory is taken. I have seen no evidence of that.

This morning I found the wall facing the sunrise had grown half an inch during the night. I measured, found the growth to be true and accurate. (OSNS, 18)

Alexie's anxiety that "the reservation will become smaller" is based on historical precedence; the doctrine of Manifest Destiny has severely diminished native lands. Although Alexie finds no evidence that the Reservation is losing ground, he does discover that the eastern wall of his house is slowly gaining in height. The wall becomes a vertical barrier, another way to diminish native lands by enclosing them; although he has carefully measured every morning to ensure that he does not literally lose ground, the constraints of the Reservation are closing in on him. Thus, the house turns into a miniature Reservation, cutting off the sunrise and its attendant association with new beginnings.

In another prose poem "The Mice War", the reservation constricts even further, to the extent that it shows how far the external restrictions of the reservations become internalized, causing self-perpetuating cycle of self-loathing, hatred and violence. This attitude may be attributed to what Eduardo Duran and Bonnie Duran term the 'soul wound', a wound that occurred "at a very deep psychological level" within an individual or community and "overwhelmed and destroyed the world" ${ }^{24}$ for Native American people. This 'soul wound' affects the Native American's perception of the world, causing him to view it as hostile. "The Mice War" tells that his frustration against the circumstances on Reservation has erupted into an act of violence even against the mice:

We dumped six garbage cans and watched dozens of mice race for their lives across the gray sand of the reservation landfill. With shovel and broom stick, my cousin and I chased them down. I beheaded twenty-seven before I simply beat one mouse into a red puddle. The reservation had taught me to hate, so it was easy to hate the mice. 


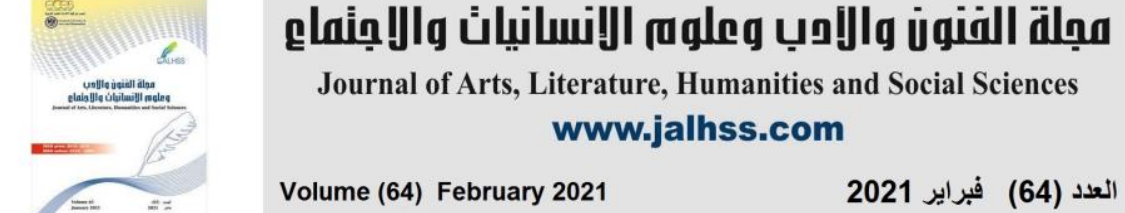

I swung the shovel until my hands blistered. I killed mice because they were mice. I swung the shovel until I could barely raise my arms. I hated the reservation because it was the reservation. It was my reservation.

I swung that shovel until the surviving mice ran into the thick grass on the perimeter of the fill. I chased them down. I beat the grass because it was grass. I hated the grass because the reservation had taught me to hate grass. I chased that last mouse into the last corner. There, in that place, I stepped on that mouse because it was a part of all mice. I broke its spine because my reservation believed in broken spines, because my reservation believed in blood, because my reservation believed in mice and the broken spines and the blood of mice. $\underline{(O S N S}, 60)$

Native Americans living on Reservations try to find the means to temporarily escape from their real harsh conditions through alcohol. Many of Alexie's main characters struggle to escape life on the Reservation. Lester in the above-mentioned poem, "The Unauthorized Biography of Lester Falls Apart", is an alcoholic who has become emotionally, economically and spiritually deadened. Lester barely subsists on his military pension and by carrying groceries for old women, ultimately spends his money on alcohol:

Old women

pay Lester a few dollars

to carry groceries

from the Trading Post.

Old men

give Lester a shot

from their whiskey bottles

in a tribal gesture.

On warm nights

Lester sleeps

under a picnic table

in the BIA compound. (OSNS, 51)

As Stephen Evans points out "Alexie raises audience's awareness regarding alcoholism and contextualizes it in a way that is deeply critical of colonial history and its impact on Native people." ${ }^{25}$ It has been estimated that alcohol and drugs lead to more than half of the deaths on Reservations. Fergus Bordewich writes that: 


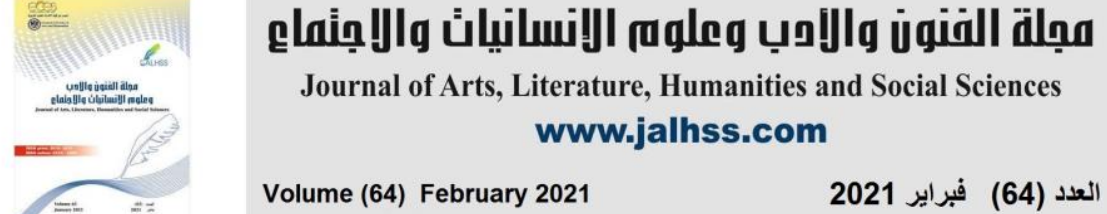

The cumulative effect of alcoholism on Indians is staggering. According to the Indian Health Service, Indians are three and a half times more likely than other Americans to die from cirrhosis of the liver, a benchmark of addiction. They are also four times more likely to die from accidents, and three times more likely to die from homicide and suicide, in all of which alcohol is usually present....Alcohol also takes an immeasurable toll in chronic disability, lost earning capacity, unemployment, emotional pain, family disruption, and child abuse. ${ }^{26}$

In writing about alcohol addiction among Native Americans, Alexie is attempting to draw both whites and Native Americans into his critical analysis of contemporary Native American life in order to promote change. While the picture of Reservation alcoholism may be harsh, if change is to occur, it is necessary to have a hard look at it. This hard look implies shared responsibility. If the origin of alcohol abuse can be traced to the introduction of that addictive drug by early white settlers into Native American life, it is still the Native Americans who face the challenge of breaking that addiction. Stephen Evans points out that Alexie's call for change makes him a "moral satirist":

Alexie has essentially moral aims in writing poetry and fiction that is heavily infused with irony and satire. Much of Alexie's work to date comprises a modern survival document from which his readers gain strength by actively participating in the recognition of reality as viewed through Alexie's satiric lens. ${ }^{27}$

The poem "House Fires" reveals the devastating and destructive effects of alcohol on the life of Alexie's family. Alexie's father comes home drunk and smashes the furniture, forcing his mother to escape the house:

The night my father broke the furniture and used the pieces to build a fire, my mother tore me from my bed at 3 a.m. Eyes and mouth wide with whiskey, she told me we were leaving that place and would never come back. We drove for hours, under the gates of this reservation, as she recanted years of life with my father, the man who pulled our house from its foundations and sent us all tumbling down to a cafe in Colville. $(B F S, 29)$ 


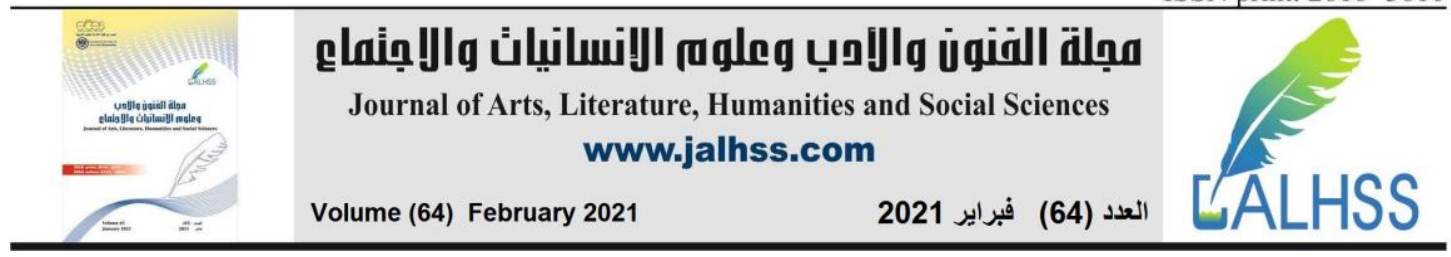

In his prose poem "The Unauthorized Biography of Me", Alexie remembers his father, "My father is an alcoholic. He used to leave us for weeks at a time to drink/ with friends and cousins." $(\text { OSS, 24) })^{28}$

Alexie believes that the root of the contemporary problems of Alcohol abuse suffered by Native Americans is a result of colonization. In "My Heroes Have Never Been Cowboys", he explains how the early white settlers discovered a way to gain control over the Native Americans:

Win their hearts and minds and we win the war. Can you hear that song echo across history? If you give the Indian a cup of coffee with six cubes of sugar, he'll be your servant. If you give the Indian a cigarette and a book of matches, he'll be your friend. If you give the Indian a can of commodities, he'll be your lover. He'll hold you tight in his arms, cowboy and two-step you outside. $(\text { FIOM, 102) })^{29}$

Alexie shows here his strong distaste for the methods of the early white settlers in gaining Native American cooperation: make Native Americans dependent on the products of the white man and they will always comply to keep those things accessible. He is pointing out how Native Americans have been bought via the products of white culture: cigarettes, coffee, sugar, alcohol, and food supplies.

The prose poem "The Native American Broadcasting System" shows Alexie's use of irony to address the issue of alcohol abuse:

NEWS BULLETIN: The Adolph Coors Corporation is sponsoring a new promotional contest. On the bottom inside of every beer can and bottle, Coors had printed a single letter. The first Indian to collect and spell out the word RESERVATION will receive a train ticket for a special traveling back 555 years. (FIOM, 85)

The huge corporation, the Adolph Coors Corporation, which symbolically represents white America's economic power, is promoting a contest that involves loads of drinking. Furthermore, if one could spell out the word that represents Native American suffering best, 'RESERVATION', he is awarded the grand prize of a trip back to the time when the earliest settlers colonized North America. So much can be seen in this brief passage: Alexie establishes the awful results of the historical abuses brought on by the introduction of European goods to Native American culture as he illustrates the power and control of the colonizers over the Native Americans.

In the same poem, "The Native American Broadcasting System", Alexie creates a parodic caricature of an American iconic figure, General George Armstrong Custer( 1839-1879), who was a United States Army officer and cavalry commander in the American Civil War and the Indian Wars, to comment on alcohol abuse among Native Americans: 


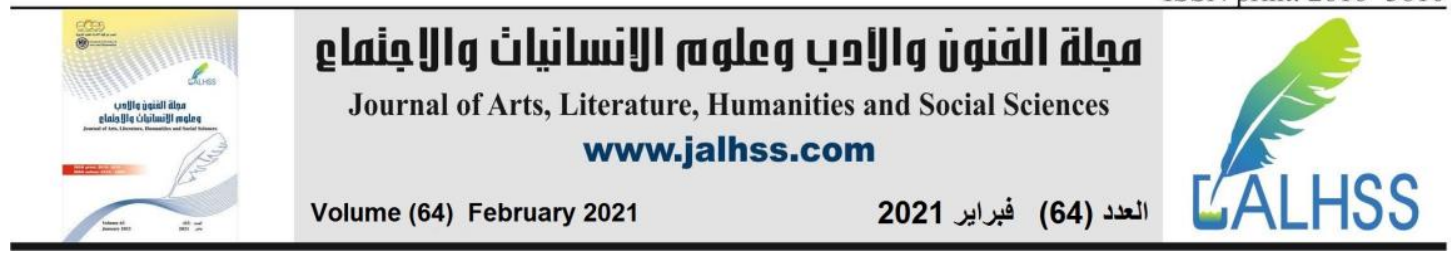

Custer came back to life in Spokane managing the Copper Penny Grocery, stocked the rubbing alcohol next to the cheap wine: RUBBING ALCOHOL 99 cent, THUNDERBIRD WINE \$1.24. The urban Indians shuffle in with tattered coats and boots, counting quarters while Custer trades food stamps for cash." $(F I O M, 84)$

As an icon of white American history, Custer is typically thought of as a brilliant American soldier who fought to end the war launched by the Sioux and Cheyenne tribes against white settlers in the 1870's. The parody is evident as Alexie turns Custer into a grocery store manager who now conquers Native Americans by putting "rubbing alcohol" next to wine on store shelves. "The rubbing alcohol" is cheaper than the wine. Custer, while managing his grocery store, is continuing his earlier work as a killer of Native Americans. The cheaper "rubbing alcohol" would kill faster than the "Thunderbird wine", and that may be the reason for the product placement and price. This symbolism insinuates that Native Americans will drink anything as long as it contains alcohol.

Alexie believes that Native Americans are also responsible for alcohol abuse. In the prose poem "Giving Blood", the famous Native American hero Crazy Horse is viewed in a humorous manner. Desperate for money to buy alcohol, Crazy Horse donates blood:

I need money for the taxi cab ride home to the reservation and I need a taxi because all the Indians left this city last night while I was sleeping and forgot to tell me, so I walk on down to the blood bank with a coupon that guarantees me twenty bucks a pint and I figure I can stand to lose three or four pints. $(B F D, 78)$

The white nurse asked Crazy Horse a number of questions:

I need the money so I sit down at a wooden desk across from the white nurse holding a pen and paper and she asks me my name and I tell her Crazy Horse and she asks my birthdate and I tell her it was probably June 25 in 1876 and then she asks my ethnic origin and I tell her I'm an Indian or Native American depending on your view of historical accuracy and she asks me my religious preference and I tell her I prefer to keep my religion entirely independent of my economic activities and then she puts aside her pen and paper and gives me the most important question she asks me if I still have enough heart and I tell her I don't know it's been a long time but I'd like to give it a try. $(B F D, 78)$

Finally, Crazy Horse is rejected by the white nurse who says:

I'm sorry Mr. Crazy Horse but we've already taken 


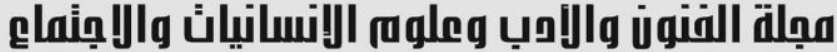 \\ Journal of Arts, Literature, Humanities and Social Sciences \\ www.jalhss.com \\ Volume (64) February 2021 \\ العدد (64) فبراير 2021}

Too much of your blood and you won't be eligible

to donate for another generation or two. $(B F D, 78)$

Alexie envisions a contemporary Crazy Horse in "War All the Time" as an alcoholic Vietnam veteran who sells his medals:

Crazy Horse sells his medals

When he goes broke, buys a dozen beers

And drinks them all. $(B F D, 65)$

When the bartender "asks him why / he's giving up everything he earned" $(B F D, 65)$, Crazy Horse tells him "you can't stop a man / from trying to survive, no matter where he is." $(B F D, 65)$

Alexie treats the issue of alcohol addiction with varied humorous critical modes in an effort to enlighten Native Americans of its serious results. Such treatment is crucial to the survival of his people because it helps them face problems, learn to deal with them, and move toward change. As Vine Deloria puts it:

The more desperate the problem, the more humor is directed to describe it. Satirical remarks often circumscribe problems so that possible solutions are drawn from the circumstances that would not make sense if presented in other than a humorous form." ${ }^{30}$

In the prose poem "Evolution", Buffalo dance

31, who represents corrupt Western materialism and consumerism, is used as a symbol to comment on alcohol abuse among Native Americans and the commodification of their culture:

Buffalo Bill opens a pawn shop on the reservation right across the border from the liquor store and he stays open 24 hours a day, 7 days a week. $(B F D, 48)$ alcohol:

Native Americans living on Reservation pawn everything, in order to buy

And the Indians come running in with jewelry, television sets, a VCR, a full-length beaded buckskin outfit it took Inez Muse 12 years to finish. Buffalo Bill takes everything the Indians have to offer, keeps it all catalogued and filed in a storage room. The Indians pawn their hands, saving the thumbs for last. They pawn their skeletons, falling endlessly from the skin. $(B F D, 48)$

Native Americans pawn everything to Buffalo Bill. They pawn all they own, including a "beaded buckskin outfit," which can be seen as a cultural symbol that significantly represents native identity. In fact, the maker of that buckskin outfit, Inez Muse, carries a symbolic notion along with her name: a muse is a source of inspiration, and it appears that Alexie, in using this name, is making a statement about a great loss of inspiration, and thus, of native 


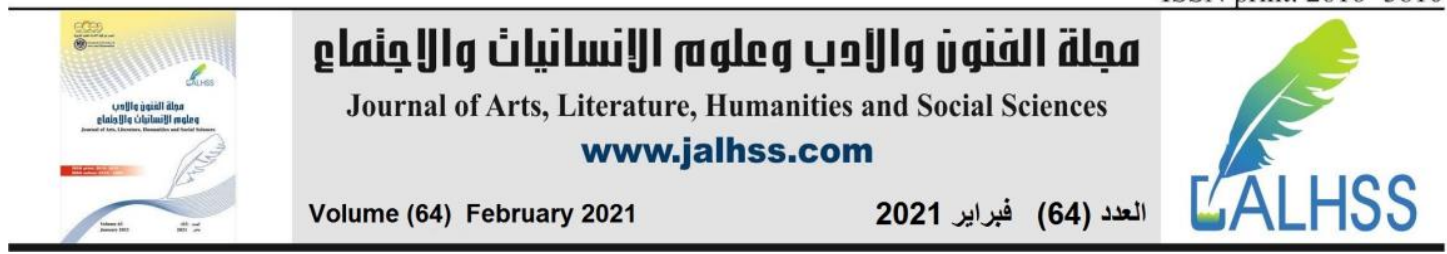

culture as a white man takes this cultural symbol for his own greedy motivations. Buffalo Bill collects and catalogs everything the Native Americans have pawned. He closes the shop and reopens it as "THE MUSEUM OF NATIVE AMERICAN CULTURES":

And when the last Indian has pawned everything but his heart, Buffalo Bill takes that for twenty bucks closes up the pawn shop, paints a new sign over the old, calls his venture THE MUSEUM OF NATIVE AMERICAN CULTURES charges the Indians five bucks a head to enter. $(B F D, 48)$

When Buffalo Bill has taken everything, he closes the doors of the pawn shop, sealing out the possibility of Native Americans' repossession of their culture. The fact that Native Americans have pawned away their culture illustrates its exploitation by the Americans.

This exploitation of Native American culture is also the subject of "The Business of Fancydancing." This poem shows how fancydancing has deteriorated from a high cultural art into a cold, economic necessity. Clyde Ellispoints out that:

Fancydancing is a traditional form of Native American dance which was originally created by members of the Ponca tribe in the 1920s and 1930s, in an attempt to preserve their culture and religion." 32

The poem shows that a traditional a cherished native dance has been materialized: After driving all night, trying to reach

Arlee in time for the fancydance

finals, a case of empty

beer bottles shaking our foundations, we

stop at a liquor store, count out money,

and would believe in the promise

of any man with a twenty, a promise

thin and wrinkled in his hand, reaching

into the window of our car. Money

is an Indian Boy who can fancydance

from powwow to powwow. $(B F D, 69)$

The speaker in the poem moves with his friend, Vernon Wildshoe, a champion fancydancer, from powwow to powwow only to get solely money, not to celebrate a cultural heritage or connect with other Native American tribes Vernon's dances are motivated getting so that the two friends can buy alcohol:

We get Vernon there in time for the finals and we watch him like he was dancing on money, which he is, watch the young girls reaching 


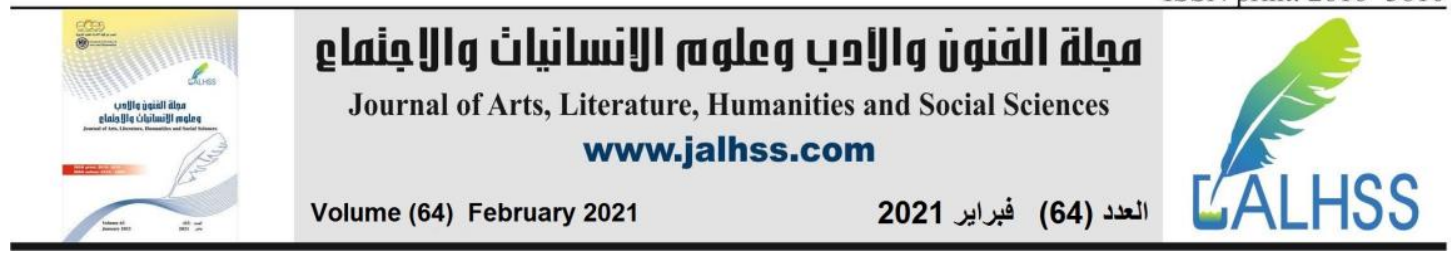

for him like he was Elvis in braids and an empty tipi, like Vernon could make a promise

with every step he took, like a fancydance

could change their lives. We watch him dance

and he never talks. It's all a business we

understand. $(B F D, 69)$

Alexie depicts in his poetry the reality of the Reservation life in its negative and positive aspects. For Alexie, survival of Native Americans will be achieved through the resilience of their cultural values and ceremonies. Though economic and social conditions on the Reservations are harsh, they also represent a haven in which Native Americans can maintain their cultural values and traditions. They can be shelters from the dominant American culture. The prose poem "Powwow Polaroid" expresses the idea that native traditional ceremonies face the threat of being commercialized or tainted by non-Natives, who do not attempt to understand the culture they witness but rather regard it as mere spectacle for entertainment. A white tourist tries to steal a picture of the fancy dancers to be used by the CIA:

We were fancy dancing, you see.

Step-step, right foot, step-step, left foot, faster, twisting, turning, spinning, changing.

There are photographs taken but only one ever captured the change.

It was a white tourist from Spokane. She was lucky, she was quick, maybe it was film developed by the CIA. (OSNS, 43)

Alexie describes the impact of all those black and white photographs that fixed Native Americans forever in mock-ceremonial poses. As these tourist images were commodified, Native Americans were expected to embody them:

She took the picture, the flashbulb burned, and none of us could move. I was frozen between steps, my right foot three inches off the ground, my mouth open and waiting to finish the last sound. (OSNS,43)

Alexie thinks that Native American ceremonies and gatherings represent Native Americans' insistence on the preservation of their native identity and cultural survival. The speaker in the poem "Powwow" observes that amidst the celebrations:

Today, nothing has died, nothing changed beyond recognition dancers still move in circles" (BFD, 52).

In the prose poem "Gravity", Alexie claims that most Native Americans living on Reservations still maintain a sense of ethnic identity and community; "every Indian has the blood of the tribal memory circling his heart. The Indian, no matter how far he travels away, must come back, repeating, joining the reverse exodus." $(B F D, 80)$ 


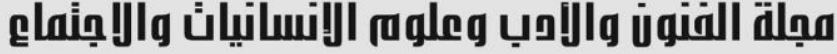

SSN print: $2616-3810$

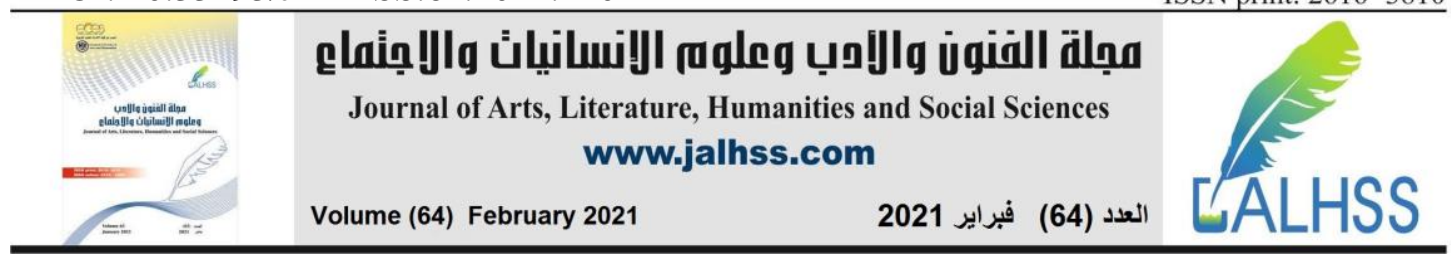

\section{Conclusion}

Sherman Alexie aims in his poetry to depict the harsh and drastic social, political, economic, and cultural aspects of the lives of Native Americans living on Reservations. At the same time, he emphasizes the need to revive Native American heritage and traditions as a means to preserve their native identity and cultural survival.

\section{Endnotes and References}

1 See Brian Dippie, The Vanishing American: White Attitudes and U.S. Indian Policy (Lawrence: University Press of Kansas, 1982), 151.

2 Kai, Erikson, "Notes on Trauma and Community," Caruth Trauma 183-99.

3 Åse Nygren, Tracing Trauma: The Narration of Suffering in Sherman Alexie's Fiction ( Diss. Göteborg Uni., 2007(, 70.

4 Nancy Peterson, ed., Conversations with Sherman Alexie (Jackson: UP of Mississippi, 2009), 171.

5 Irene S. Vernon, Killing Us Quietly: Native Americans and HIV/AIDS (Lincoln: University of Nebraska Press, 2001), 6.

6 Jace Weaver, That The People Might Live: Native American Literatures and Native American community (New York: Oxford University Press,1997),11.

7 Rennard Strickland, Tonto's Revenge: Reflections on American Indian Culture and Policy (Albuquerque: University of New Mexico Press, 1997), 53.

8 Lynn Cline ,"About Sherman Alexie", Ploughshares, Vol. 26, No. 4 (Winter, 2000/2001), 197.

9 Quoted in Joseph Bruchac, Smoke Rising: The Native North American Literary Companion (Detroit: Visible Ink, 1995),2.

10 Quoted in Joel McNally, "Sherman Alexie", Writer 114, no. 6 (June 2001), 29.

11 Quoted in Bruce E. Johansen, ed., Native Americans Today: A Biographical Dictionary (California: Greenwood 2010), 7 .

12 Quoted in Joseph L. Coulombe, "The Approximate Size of His Favorite Humor Sherman Alexie's Comic Connections and Disconnections in The Lone Ranger and Tonto Fistfight in Heaven," in The American Indian Quarterly, Volume 26, Number 1, Winter (2002);104.

13 Quoted in Daniel Grassian, Understanding Sherman Alexie (South Carolina: University of South Carolina Press,2005),20.

14 Alan R. Pratt credits French surrealist poet and critic Andre Breton with having coined the term "humor noir" (dark or black humor). Black humor is used to designate a sub-genre of comedy and satire in which laughter arises from cynicism and skepticism often about the topic of death. See Alan R. Pratt, Introduction to Black Humor: Critical Essays (London: Routledge, 1992) xx.

15 Paula Gunn Allen, The Sacred Hoop: Recovering the Feminine in American Indian Traditions (Boston: Beacon, 1986), 159.

16 Ibid. 


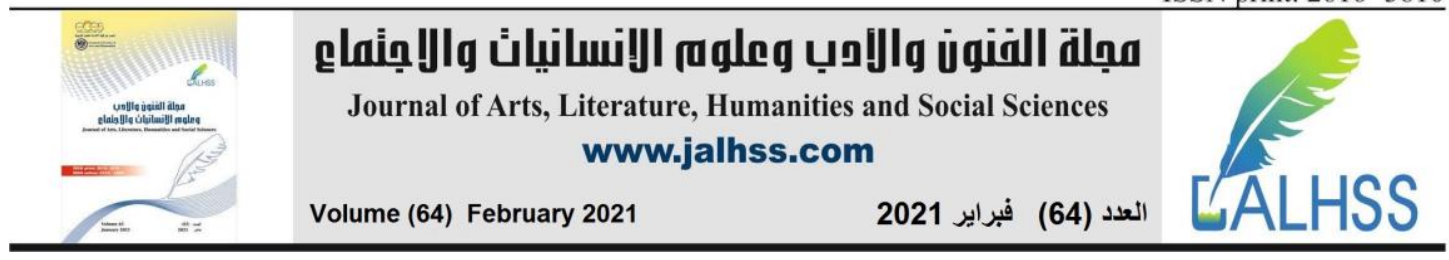

17 Louise Erdrich et al., Conversations with Louise Erdrich and Michael Dorris (Jackson: University Press of Mississippi, 1994), 209.

18 Quoted in Grassian, Understanding Sherman Alexie, 2.

19 Jane Hafe, ed., Dreams and Thunder: Stories, Poems, and The Sun Dance Opera (Lincoln: University of Nebraska Press, 2001), 175.

20 Philip Heldrich, "Survival = Anger x Imagination": Sherman Alexie's Dark Humor" in Jeff Berglund and Jan Roush eds., Sherman Alexie: A Collection of Critical Essays. (Michigan: Sheridan Books, Inc., 2010),

21Sherman Alexie, The Business of Fancydancing: Stories and Poems (New York: Hanging Loose Press, 1992. All subsequent quotations of poems of this volume are taken from this edition and will be cited by abbreviated title and page number in parentheses after quotations.

22 HUD is The United States Department of Housing and Urban Development. It was founded in 1965 as part of the "Great Society" program of President Lyndon Johnson, to develop and execute policies on housing and cities.

23 Sherman Alexie, Old Shirts and \& New Skins (California: Pace Publication Arts, 1993). All subsequent quotations of poems of this volume are taken from this edition and will be cited by abbreviated title and page number in parentheses after quotations. 24 Eduardo Duran and Bonnie Duran, Native American Postcolonial Psychology (Albany: State University of New York, 1995), 195.

25 Stephen Evans "Open Containers: Sherman Alexie's Drunken Indians", American Indian Quarterly, Winter (2001), vol. 25, no. 1: 54.

26 Fergus Bordewich, Killing the White Man's Indian: Reinventing Native Americans at the End of the Twentieth Century (New York: Anchor, 1997), 248.

27 Evans, “Open Containers: Sherman Alexie's Drunken Indians", 59.

28 Sherman Alexie, One Stick Song (New York: Hanging Loose Press, 2000). All subsequent quotations of poems of this volume are taken from this edition and will be cited by abbreviated title and page number in parentheses after quotations.

29 Sherman Alexie, First Indian on the Moon (New York: Hanging Loose Press, 1993.) All subsequent quotations of poems of this volume are taken from this edition and will be cited by abbreviated title and page number in parentheses after quotations. 30 Vine Deloria, Jr., Custer Died for Your Sins: An Indian Manifesto (Norman: University of Oklahoma Press, 1988),147.

31 Frederick "Buffalo Bill" Cody (1846 -1917) was an American soldier, bison hunter and showman. He got his nickname after he undertook a contract to supply Kansas Pacific Railroad workers with buffalo meat. By his own count, he killed 4,280 head of buffalo in eighteen months. See Tom Thomas, ed., An Autobiography of Buffalo Bill Cody (Black Oyster Publishing Company, Inc., 2010), 63.

32 Clyde Ellis, A Dancing People: Powwow Culture on the Southern Plains (Lawrence: University of Kansas Press, 2003),111. 